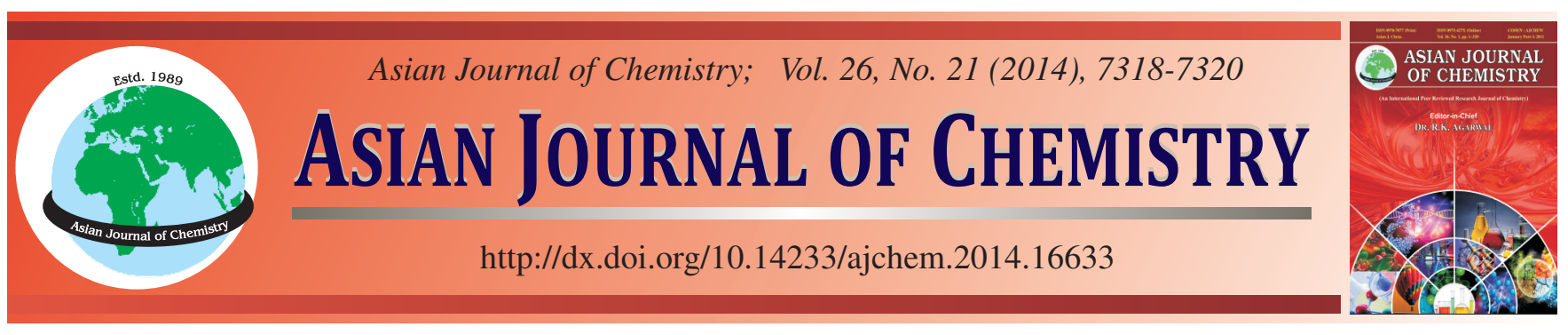

\title{
Electrochemical Removal of Chemical Ammonia Nitrogen from Biologically Pretreated Coking Wastewater Using Immobilized Three-Dimensional Electrodes
}

\author{
HAO W $\mathrm{ANG}^{1, *}$ and XUEJIN $\mathrm{Li}^{2}$
}

${ }^{1}$ College of Civil and Architecture Engineering, Hebei United University, Tangshan, P.R. China

${ }^{2}$ Department of Foreign Languages, Tangshan College, Tangshan, P.R. China

*Corresponding author: E-mail: wanghao1689@gmail.com

\begin{abstract}
Electrochemical oxidation of ammonia nitrogen contained in biologically pretreated coking wastewater treated by three-dimensional electrode system with combined modified coke served as packed bed particle electrodes and $\mathrm{Ti} / \mathrm{RuO}_{2} / \mathrm{IrO}_{2}$ anode was studied. At the same time the influence of retention time, plate spacing, $\mathrm{A} / \mathrm{V}$ (area/volume) and current density on ammonia nitrogen removal efficiency with combined three-dimensional electrodes was also investigated. The results show that the three-dimensional electrodes in combined process could effectively decompose ammonium. For plate distance of $1 \mathrm{~cm}$, retention time of $40 \mathrm{~min}$ and current density of $9 \mathrm{~mA} / \mathrm{cm}^{2}$, the highest removal efficiency of nitrogenous compounds was achieved. The ammonia nitrogen removal efficiency can reach more than $90 \%$.
\end{abstract}

Keywords: Coking wastewater, $\mathrm{Ti} / \mathrm{RuO}_{2} / \mathrm{IrO}_{2}$ electrodes, Current effiency, Anode plate.

\section{INTRODUCTION}

As part of our systematic investigation on wastewater treatment, the present study describes contamination contained in biologically pretreated coking wastewater ${ }^{1-4}$. Most of these constituents are refractory, toxic, mutative and carcinogenic. Thus, it is necessary to be treated to reduce any possible impacts on the aquatic environment. There are several conventional coking wastewater treatment methods, including solvent extraction of phenolic compounds, steam stripping of ammonia and biological treatment (mostly the activated sludge process) and many treatment processes have been studied. Although the biological methods are very effective for the disposal of wastewater $^{5-9}$, but they also have some difficulties to achieve the strict requirements of the National Discharge Standard of China $\left(\mathrm{COD}<150 \mathrm{mg} \mathrm{L}^{-1}, \mathrm{NH}_{3}-\mathrm{N}<25 \mathrm{mg} \mathrm{L}^{-1}\right)^{10}$ and the cost are also very high. Therefore, great attention has been directed toward new techniques for coking wastewater treatment.

Some researchers showed that titanium substrate coating anode plates had good effect on electrochemical oxidation and wastewater treatment ${ }^{11}$. According to Richardson and Qian ${ }^{12}$, inter layer added $\mathrm{RuO}_{2}$ and $\mathrm{IrO}_{2}$ oxide paint-coat could enhance the stability and prolong the lifetime. In order to get better implementation of the comprehensive utilization of waste, we select $\mathrm{Ti} / \mathrm{RuO}_{2} / \mathrm{IrO}_{2}$ anode with coke powder as the 3-D electrode.

EXPERIMENTAL

Electrolysis was carried out relying on the electrolytic device which consisted of coke, the electrolytic cell, electrode plates and DC power supply (MPS702). Electrochemical plates consisted of stainless steel cathode plates and titanium substrate anode plates coated with noble metals oxide which including $\mathrm{RuO}_{2}$ and $\mathrm{IrO}_{2}$. The electrolytic cell was made of synthetic glass with a dimension of $140 \mathrm{~mm} \times 90 \mathrm{~mm} \times 130 \mathrm{~mm}$ and an effective volume was $1.3 \mathrm{~L}$. Specification of each plate was $130 \mathrm{~mm} \times 65 \mathrm{~mm} \times 1 \mathrm{~mm}$. The schematic diagram of main apparatus is shown in Fig. 1.

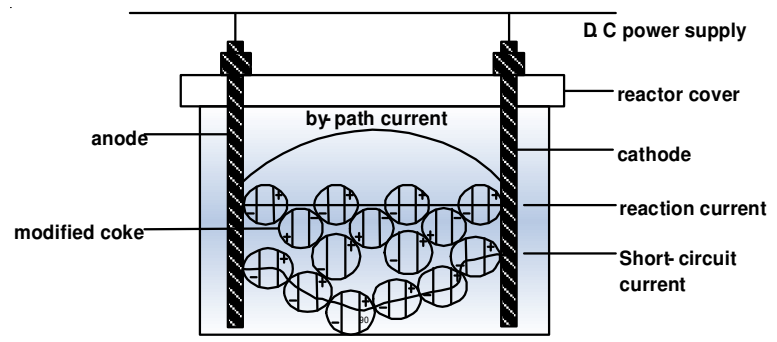

Fig. 1. Schematic diagram of the experimental apparatus

Experimental materials: The coking wastewater used for this study was obtained from secondary sedimentation tank at the Shou Gang Coking Plant. The characteristics of the wastewater is shown in Table-1. 


\begin{tabular}{ccc}
\hline \multicolumn{3}{c}{ TABLE-1 } \\
CHARACTERISTICS OF WASTEWATER \\
USED IN THE EXPERIMENTS \\
\hline Parameter & Unit & Concentration \\
\hline $\mathrm{pH}$ & - & 5.94 \\
Chemical oxygen demand, COD & $\mathrm{mgL}^{-1}$ & 304.09 \\
$\mathrm{NH}_{3}-\mathrm{N}$ & $\mathrm{mgL}^{-1}$ & 131.31 \\
$\mathrm{TN}$ & $\mathrm{mgL}^{-1}$ & 132.25 \\
Chloride ions concentration & $\mathrm{mgL}^{-1}$ & 748.85 \\
Turbidity & NTU & 4.80 \\
\hline
\end{tabular}

The coke was obtained from a coke bin in coking plant at Tangshan city and the property of coke is shown in Fig. 2.

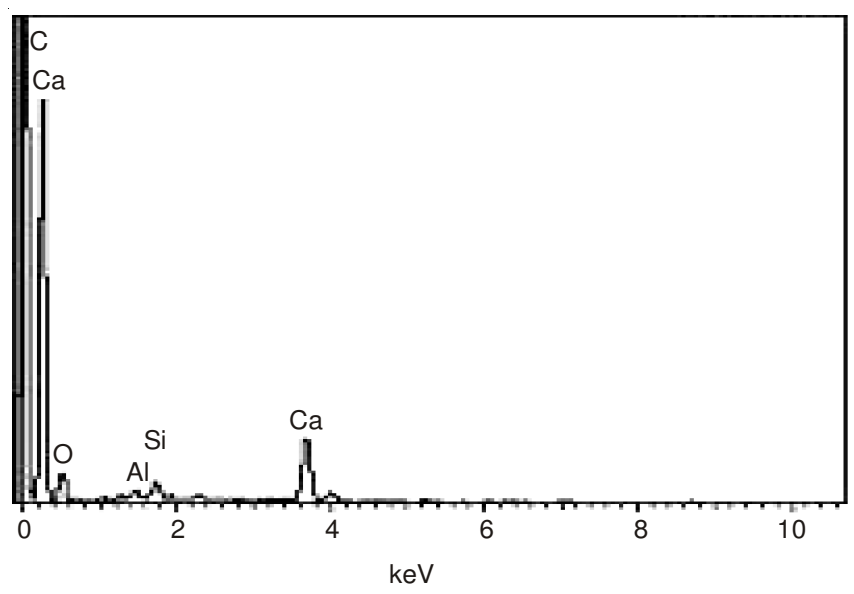

Fig. 2. Elemental percentage spectrum of coke powder used in the experiments

Methodology: In order to optimize the three-dimensional electrode process using $\mathrm{Ti} / \mathrm{RuO}_{2} / \mathrm{IrO}_{2}$ anode and the modified coke particles, electrolysis of coking wastewater was carried out under different current density, $\mathrm{pH}$ and temperature. Moreover, we examined the properties of $\mathrm{Ti} / \mathrm{RuO}_{2} / \mathrm{IrO}_{2}$ anode cell and modified coke particles through SEM and EPS briefly. Finally, the removal mechanisms of ammonia nitrogen in the three-dimensional electrode process using $\mathrm{Ti} / \mathrm{RuO}_{2} / \mathrm{IrO}_{2}$ anode and the modified coke particles were investigated.

\section{RESULTS AND DISCUSSION}

As shown in Fig. 3, the evolution of $\mathrm{NH}_{3}-\mathrm{N}$ concentration as a function of electrolysis time at different particle sizes of coke particles ( $\geq 5,5-10,10-20$ and 20-40 mesh).The removal rates of $\mathrm{NH}_{3}-\mathrm{N}$ increased with the decrease of particle size, but the increase in the rate of $\mathrm{NH}_{3}-\mathrm{N}$ reduction is not significant for over 20 mesh. And the removal rate of 10-20 mesh is the highest of the four kinds of samples.

Electrochemical treatment effect: Fig. 4 showed the variation in the concentration of ammonia nitrogen compounds as a function of electrolysis time in the presence of different electrodes. Before the experiment, the coke was dried at $105^{\circ} \mathrm{C}$ in oven for $2 \mathrm{~h}$ and immersed in coking wastewater for $12 \mathrm{~h}$, respectively to avoid the effect of absorption. As can be seen from Fig. 3, in the same electrolysis conditions, the ammonia nitrogen of the 3D reactor removal achieved $90 \%$ at $40 \mathrm{~min}$, while the $2 \mathrm{D}$ reactor in the same period is only about $75 \%$. After $1 \mathrm{~h}$, the ammonia nitrogen removal of two reactors

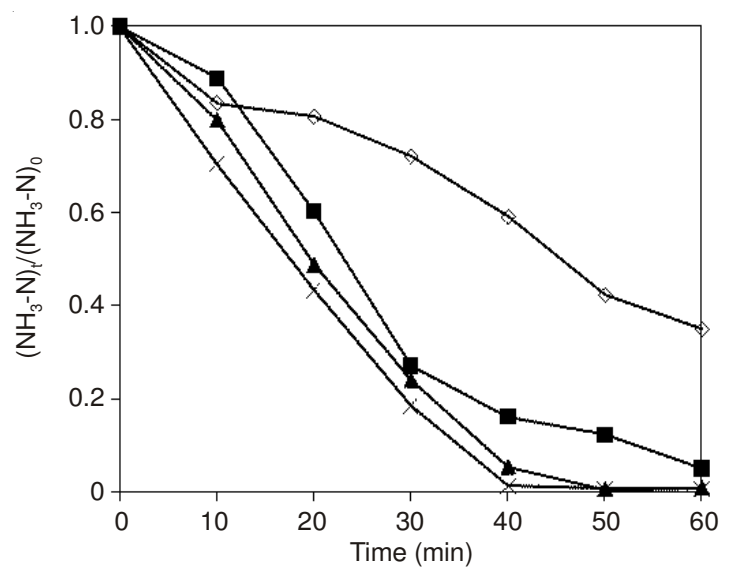

Fig. 3. Effect of different code powder diameter on removal efficiency of $\mathrm{NH}_{3}-\mathrm{N}:(\square)$ = 5 mesh, $(\boldsymbol{\Delta})$ 5-10 mesh $(\times)$ 10-20 mesh $(\diamond)$ 20-40 mesh

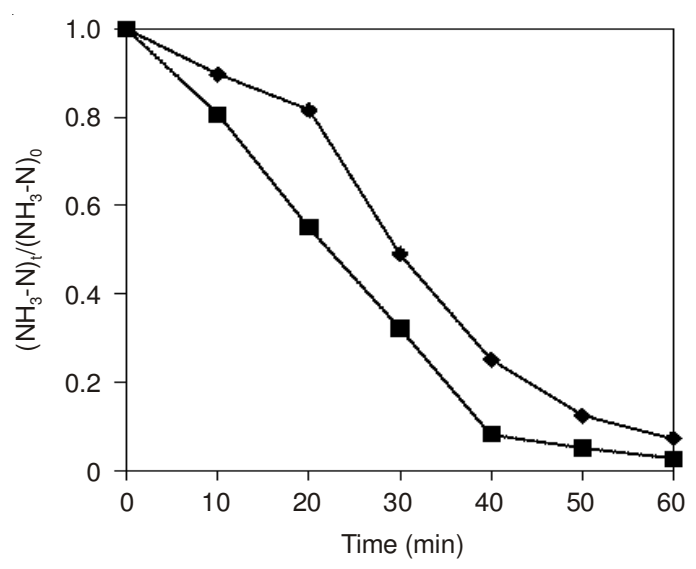

Fig. 4. 2-D and 3-D electrodes on the electrochemical removal of $\mathrm{NH}_{3}-\mathrm{N}$ compouds from biologically pretreated coking wastewater for the electrolyses performed at $9 \mathrm{mAcm}^{-2}$ on the $\mathrm{Ti} / \mathrm{RuO}_{2} / \mathrm{IrO}_{2}$ electrode:

( $)$ 2-D electrodes, ( $\square$ ) 3-D electrodes.

achieved 97 and $93 \%$, respectively. This is because that many small particles put into the 3 -D electrode system form charged microelectrodes under the influence of electric field. Coke could increase the effective area of electrodes. More importantly, the coke acted as the bipolar electrode for additional free hydroxyl radicals generation, which could greatly improve the ammonia nitrogen removal rate. All of these indicate that the 3-D electrode system should be able to give a satisfied solution to the remained bio-refractory ammonia nitrogen from the biological treatment process in comparison to conventional 2-D electrodes.

Influence of operating variables on ammonia nitrogen: When the plate spacing increases from 0.5 to $2 \mathrm{~cm}$, the characteristics of contamination removal rate were shown in the Fig. 5. It is clear from the Fig. 5 with the shorter distance of plates, $\mathrm{NH}_{3}-\mathrm{N}$ removal efficiency increased gradually. The plate spacing has a clear impact on $\mathrm{NH}_{3}-\mathrm{N}$ treatment effect, but the increase in the rate of $\mathrm{NH}_{3}-\mathrm{N}$ reduction is not significant for less than 1 $\mathrm{cm}$. This is because the short distance between plates can generate the $\mathrm{H}_{2} \mathrm{O}_{2}$, free hydroxyl radicals $\left({ }^{\circ} \mathrm{OH}\right)$ increasingly, which can have an effect on the degradation of ammonia nitrogen. Plates resistance will increase and the current through the plates will decrease if the plate spacing get less than $1 \mathrm{~cm}$. To sum up, the best plate spacing is $1 \mathrm{~cm}$. 


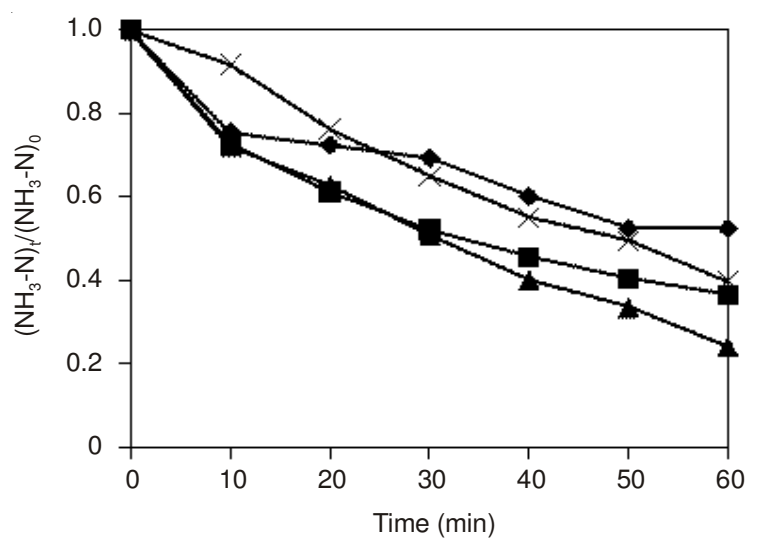

Fig. 5. Remove mate of different plate distance on removal efficiency of $\mathrm{NH}_{3}-\mathrm{N}:(\square) 0.5 \mathrm{~cm},(\Delta) 1 \mathrm{~cm},(\times) 1.5 \mathrm{~cm},(\square) 2 \mathrm{~cm}$

Influence of $\mathrm{A} / \mathrm{V}$ (area of plates/volume of wastewater): As shown in Fig. 6, ammonia nitrogen concentration decrease generally with the increase of $\mathrm{A} / \mathrm{V}$ and retention time at 6 $\mathrm{mA} / \mathrm{cm}^{2}$. At the constant current density condition, the increase of plate area is conducive to the generation of strong oxidizing substances as $\mathrm{H}_{2} \mathrm{O}_{2},{ }^{\circ} \mathrm{OH}$ and $\mathrm{O}_{3}$, etc. Meanwhile, it is easy to assemble pollutant to occur oxidation reaction in the plate surface owing to the large plate area, improving the ammonia nitrogen removal efficiency.

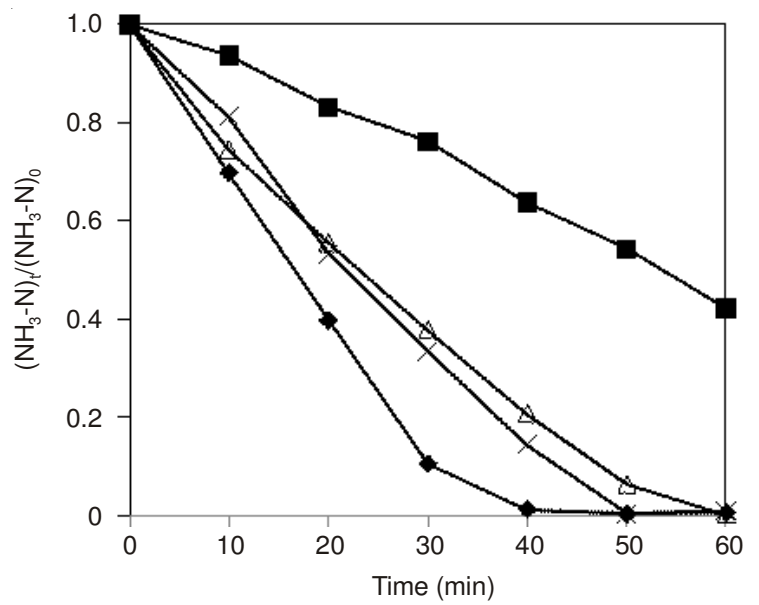

Fig. 6. Effect of area/volume on the electrochemical removal of $\mathrm{NH}_{3}-\mathrm{N}$ compounds from advanced treatment of biologically pretreated coking wastewater with 3-D electrodes: $\mathrm{m}^{2} / \mathrm{m}^{3},(\times) 101.4 \mathrm{~m}^{2} / \mathrm{m}^{3}$,

$135.2 \mathrm{~m}^{2} / \mathrm{m}^{3}$

Influence of current density: As shown in Fig. 7, the removals of ammonia nitrogen versus retention time at various current densities. The removals of the electrolytic oxidation of ammonia nitrogen increase generally with the current density and the retention time. At a current density of 4.5, 6 and $7.5 \mathrm{~mA} / \mathrm{cm}^{2}$, retention time $40 \mathrm{~min}$, the ammonia nitrogen removals are about 96.2, 98.6 and $99.9 \%$, respectively. The surplus $\mathrm{NH}_{3}-\mathrm{N}$ was almost completely removed in all solutions. It gradually increased from a low current intensity, electrolysis generated in the process. $\mathrm{OH}$ has increased, the ammonia nitrogen removal capacity increases. But the tests found that at a current density of 6 and $7.5 \mathrm{~mA} / \mathrm{cm}^{2}$ and current intensity of the sustained increases in the final mixture temperature as high as 43 and $35^{\circ} \mathrm{C}$, respectively, affect the efficiency of the

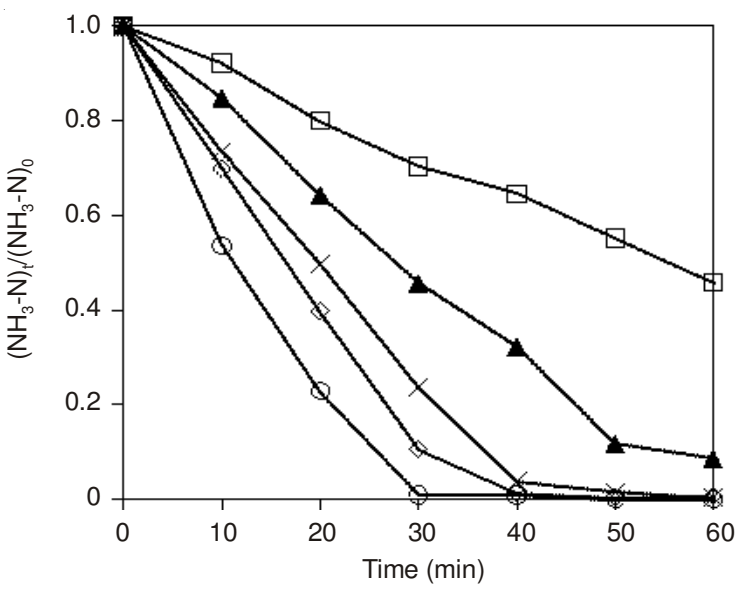

Fig.7. Effect of current density on the electrochemical removal of $\mathrm{NH}_{3}-\mathrm{N}$ compounds and the change of temperature from advanced treatment of biologically pretreated coking wastewater with 3-D electrodes (口) $1.5 \mathrm{~mA} / \mathrm{cm}^{2},(\Delta) 3 \mathrm{~mA} / \mathrm{cm}^{2},(\times) 4.5 \mathrm{~mA} / \mathrm{cm}^{2},(\diamond) 6 \mathrm{~mA} / \mathrm{cm}^{2}$, (O) $7.5 \mathrm{~mA} / \mathrm{cm}^{2}$

electrodes, the treatment effect variation, while increasing power consumption. Therefore, the best ammonia nitrogen removals value of current density is $4.5 \mathrm{~mA} / \mathrm{cm}^{2}$.

\section{Conclusion}

For plate distance of $1 \mathrm{~cm}$, retention time of $40 \mathrm{~min}$ and current density of $4.5 \mathrm{~mA} / \mathrm{cm}^{2}$, the highest removal efficiency of nitrogenous compounds was achieved: ammonia removals were about $95 \%$; the titanium substrate coating anode plate has nice surface characteristics which could make it become good electrode material.

\section{ACKNOWLEDGEMENTS}

The financial support of this research by Hebei Province Science and Technology Project (13273608) and Hebei Construction Science and Technology Research Program (2013143) are gratefully acknowledged.

\section{REFERENCES}

1. N. Mehrdadi, A. Rahmani, A.A. Azimi and A. Torbian, Asian J. Chem., 21, 5245 (2009).

2. C.C. Tanner, J.P.S. Sukias and M.P. Upsdell, Water Res., 32, 3046 (1998).

3. H. Wang and L. Zhang, Asian J. Chem., 24, 5299 (2012).

4. Y.F. Lin, S.R. Jing, D.Y. Lee and T.W. Wang, Aquaculture, 209, 169 (2002).

5. J. Chang, X.H. Zhang and R. Perfler, Fresenius Environ. Bull., 16, 1082 (2007).

6. P.A. Mays and G.S. Edwards, Ecol. Eng., 16, 487 (2001).

7. G.D. Ji, T.H. Sun, Q.X. Zhou, X. Sui, S. Chang and P. Li, Ecol. Eng., 18, 459 (2002).

8. H. Wang and X.W. He, Fresenius Environ. Bull., 20, 2890 (2011).

9. F. Rivera, A. Warren, C.R. Curds, E. Robles, A. Gutierrez, E. Gallegos and A. Calderon, Water Sci. Technol., 35, 271 (1997).

10. C.L. Yue, J. Chang and Y. Ge, Fresen. Environ. Bull., 17, 992 (2008).

11. N. Korboulewsky, R.Y. Wang and V. Baldy, Bioresour. Technol., 105, 9 (2012).

12. C.J. Richardson and S.S. Qian, Environ. Sci. Technol., 33, 1545 (1999). 